\title{
Restriction on Religious Muslim Clothes in Kazakhstan Zhansulu Muratova
}

https://doi.org/10.33542/VSS2020-1-09

\begin{abstract}
Kazakhstan has always been linked to Islam religion. However, the question of Islamic religious clothes has only arisen recently and presents a controversy in secular, contemporary Kazakhstan. The main purpose of the present article is to review the development of Islam religion, the current situation regarding Islamic garments, and the reasons why the government is cautious about the presence of Islamic garments, moreover, the decree on prohibition of wearing headscarves in schools. In addition, the right to religion will be taken into account in order to understand the situation of citizens and their fundamental rights.
\end{abstract}

Keywords: islamization, restriction, human rights, the right to religion.

\section{Introduction}

One of the well-discussed topics in many countries is the restrictions on Muslim women's clothes. It is the topic which draws the attention of people all over the world. Muslims can be found in every city, and most of Muslim women wear religious clothes. The typical garments associated with Islam religion are, for example, burka, nikab, hijab, and headscarf. They symbolize national identity and religious adherence that attract controversy in secular countries. Muslim clothes evoke uncertain feelings and tensions among people all over the world. Kazakhstan is no exception, which is bound to the following reasons. First of all, Kazakhstan is a secular state where religion is separated from the state. Second of all, Islamic garments are not part of cultural identity. In addition to this, Kazakhstan has witnessed a wave of increase in the number of pseudo-religious organizations, terrorist and extremist sects, which attract the young citizens of the country.

In this article, I would like to review the situation in Kazakhstan regarding Islamic religious clothes and restrictions in school and educational institutions, as the topic of religious clothes is becoming debated. Debates concern the manifestation of religion in school through religious garments and its acceptability in secular schools. The topic is important due to the fact that the process of Islamization is going on in its extreme shapes, and youngsters are the target group of pseudo-religious Islamic communities. Young citizens of the Republic of Kazakhstan accept unfamiliar norms and rules in religion, which evolve a form of extremism 
and terrorism in the state. In order to prevent this process, the government has adopted the Law on Religious Activities and Religious Associations. One of the articles of the law regards education and religion. Religious garments can not be worn in secular education organizations. Also, the demonstration of religious symbols in educational institutions is prohibited by the Ministerial decree of the Republic of Kazakhstan. In this way, the government tries to restrain the process of religious manifestation and keep control of it.

However, according to the Constitution of the Republic of Kazakhstan, people are free to confess religion, and they are free in their preferences. The fundamental rights are established in the second section of the Constitution. According to the first and second subparagraphs of Article 12 of the Constitution of the Republic of Kazakhstan:

"1. Human rights and freedoms in the Republic of Kazakhstan shall be recognized and guaranteed in accordance with this Constitution.

2. Human rights and liberties shall belong to everyone by virtue of birth, be recognized as absolute and inalienable, and define the contents and implementation of laws and other regulatory and legal acts."

In addition to the Constitution, Kazakhstan has ratified many international pacts on the protection of human rights such as the Universal Declaration of Human Rights, the International Covenant on Economic, Social and Cultural Rights, and the state has to abide by all norms of the documents.

The Constitution, the Law on Religious Activities and Religious Associations, and the International documents on the protection of human rights are contradictory and lead to the collision of fundamental rights. Moreover, the restriction on wearing Islamic garments is seen as a violation of the right to freedom of religion.

The issue of Islamic clothes in schools has not been solved yet and will remain unsolved due to different opinions in the society. Certain political figures in Kazakhstan have also expressed their opinions on the issue. A member of the lower house of Parliament, A. Muradov, for example, cited the following arguments:

"In Kazakhstan, 80 percent are Muslims, and they choose to wear what is allowed by their faith. But hijab is an Arabian garment; indigenous Kazakhs have never worn it. The emergence of a special regulation or law in Kazakhstan that prohibits wearing it in public places is wrong. Each school has the right to make its own decision with regard to schoolchildren's appearance. I think that short skirts for schoolgirls are worse than a hijab" (Nogoybayeva, 2017). 
On the other hand, another deputy, G. Baimakhanova pointed out that "school is a secular institution, and should stick to secular rules, including clothing. But there are religious schools - and in those, by all means, religious affiliation can be demonstrated. If parents are so deeply religious - let them hand the child over to the madrasah" (Nogoybayeva, 2017).

Moreover, I would like to argue that Islamic garments are not a part of the cultural identity by shedding light on the situation in Kazakhstan regarding the development of Islamic religion in the country since the time of the Soviet Union. Also, I aim to present a general picture about wearing Religious clothes in Kazakhstan and the necessity of strict legislative measures. Besides this, I shall argue that people in Kazakhstan have the right to freedom of religion, and that the exclusion of students from school due to their religious attributes is legal and does not violate their rights.

\section{Islam in Kazakhstan}

Islam religion is one of the main and important religions in the Republic of Kazakhstan. The development of Islam in Central Asian countries, and in Kazakhstan particularly, has some main chronological frames. The penetration of religion was the first stage which occurred in the late $19^{\text {th }}$ century in Kazakhstan. In the article Islamic education in Central Asia: evidence from Kazakhstan, Kazakhstan embraced Islam significantly later than other Central Asian countries (Achilov, 2012).

The main reason for this was the nomadic lifestyle of Kazakhs. Kazakh people were not settled in a particular place, and Islam did not spread in a mosque-spread manner, according to the author (Achilov, 2012). Another crucial opinion of many researchers is that there were other religious trends that ancient Kazakhs followed.

One of them is the Tengrianism, when people believe in the spiritual energy of the Earth,the power of water, sun. As a proof to this statement, there is a book on the topic written by a one well-known Russian researcher, Aleksei Levshin.

Levshin (1832) writes about an interesting fact that Kazakhs intertwined Islam and other ancient cults. However, they did not exercise any Muslim ceremonies. Among them, he mentioned fasting, prayers.

A great Kazakh researcher and philosopher of the $19^{\text {th }}$ century, Chokan Valihanov also expressed his opinion on this matter. He stated that Islamism has not yet become our second nature (Torlanbayeva, 2017).

Kazakhstan was living for a long time in the shadow of the Russian Empire. Furthermore, Kazakhstan was under strict Soviet control during the $20^{\text {th }}$ century that is also reflected in the current model of politics regarding religion and state. 
Bennigsen (1983) describes the nature of Soviet politics regarding religion, i.e. politics of isolation, politics of assimilation, politics of separation, and antireligious propaganda. All of these national politics have led to a separation of religion and the state, or as we call it secularism. Interestingly, the Soviet authority's prevention of religion has been short and resulted in the opposite. Islam religion has been turned back to contemporary Kazakhstan. The revival of Islam has positive and negative outcomes for the Republic of Kazakhstan. One of the positives is that Kazakhstan has made steps in order to find its identity and establish official religions, even though it is criticized for giving a privilege to two religions.

For example, Sergey Marinin (2015) in his policy brief State regulation of Religion in Kazakhstan: reconsideration of approaches for the Norwegian Institute of International Affairs highlights a few key points regarding the situation of religious freedom in Kazakhstan. The first point is that the country accepts two religions. One of them is Islamic religion which follows norms of the Hanafi School, and another one is Orthodox Christianity (Marinin, 2015).

I agree with the statement that the official religions are Islam of Hanafi School and Orthodox Christianity in Kazakhstan (Migacheva and Frederick, n.d.). More people have started to confess religion. The manifestations of it are participation in Friday's prayers, growing numbers of people fasting during the holy month of Ramadan, and the increased numbers of women in Islamic garments. All of these activities have not been done previously, as I argued in this subparagraph above. The process of the revival of Islam is inhomogeneous in the country. It concerns mostly particular regions, cities, and particular age groups. Regarding age groups, it is necessary to note that the youth in Kazakhstan are more involved in religion. Around $69 \%$ of the young citizens of Kazakhstan identified themselves as believers according to a sociological survey conducted by the Youth Scientific Research Center. (National report "Youth of Kazakhstan - 2018").

According to this study, religion is seen as a cultural and historical heritage, and a moral and mandatory norm. Young people have also confirmed the fact of increasing numbers in radical views. Certainly, it is a negative consequence of the revival of Islam religion, as well as the growing number of pseudo-religious organizations. Such organizations have been seen as a danger for the republic due to the process of involving youngsters in terrorist activities. Also, terrorist attacks have been registered in cities throughout Kazakhstan and in neighboring countries in Central Asia.

Youth are the target group of radical religious ideas, which is an issue for Kazakhstan and the whole Central Asian region. Many researchers have studied the issue, and they underline the reason for spreading such radical religious ideas lies in the young generation. 
Jamie Bartlett \& Carl Miller (2011) highlight that young Muslims are perfect targets for spreading radical ideas among the population. It is likely that young people are more vulnerable. According to $\mathrm{J}$. Bartlet and $\mathrm{C}$. Miller, the factors which develop radical religious views are the following: foreign policy, discrimination, and even absence and poor quality of education.

Another important factor which exposes young people to pseudo-religion is crisis. The nature crisis can be economic (loss of work, low income), political (torture or discrimination), and social and moral (caused by personal crisis or psychological problems). Crisis makes an individual more vulnerable and susceptible to radical views. Moreover, among the primary factors are social exclusion, and marginalization, self-identity problems, a certain stage in life associated with a crisis, the impact of media and the Internet, involvement in the criminal environment, misunderstanding of the Quran, socio-economic deprivation, or psychological problems (A. Hirschfield, K. Cristman, A. Wilcox, M. Rogerson, K. Sharat ., 2012).

Young people in Kazakhstan are in the zone of the risk because they mainly face economic problems such as unemployment, low standard of living, low income, and inaccessibility to education (National report "Youth of Kazakhstan - 2018"). There are other factors that expose people in Kazakhstan to destructive religions. Due to the limitation of the present paper, these factors may be subject to further research.

To sum up, the development of Islam in the territory of Kazakhstan has had a long way. During different regimes Islam has taken ambiguous positions. However, it is important to note that religion has always been an element of people's lives. Nowadays, Kazakhstan is witnessing a wave of Islamization. As noted, the process of the revival has outcomes, which I divided into positive and negative ones. Kazakhstan has to deal with the negative results such as a radicalization, terrorism and distractive movements in religion, such as sects, to prevent harmful, radical views among citizens.

In order to prevent the development of radical religious views among its citizens and stop activities of pseudo religious organizations, the government of the Republic of Kazakhstan has taken measures to strict its policies in order to control the process of revival of religion, religious organizations and religious activities. A general picture on wearing of Islamic clothes in Kazakhstan and state policies, which are in effect in the Republic of Kazakhstan since 1991, will be discussed in the next subparagraphs.

\section{Religious garments and restriction in Kazakhstan}

The question of wearing religious Islamic clothing in Kazakhstan has started to appear recently. As I have mentioned earlier, Kazakh people are Muslims, and Islam is the dominant 
religion in the country, but at the same time, it is necessary to note that Kazakh people have never worn such clothes as burka, hijab or nikab.

Discussions about the issue of dress code in school and university are still going on in the country. The government of the Republic of Kazakhstan became interested in what pupils and students wear when some girls stopped to wear school uniforms and wrapped themselves in Islamic clothes. Kazakh girls wearing Islamic clothes have been expelled from schools. The conflict on the restrictions spread around the country, and by 2016 the Ministry of Education and Science had received 6000 appeals from different regions. The trend of wearing religious clothes is observed in most regions in Kazakhstan nowadays. Since 2017 around 300 girls have been expelled from school in Aktobe and other regions. Between October and December 2017, several dozens of parents from the West Kazakhstan Region, Aktobe Region, and Atyrau Region tried to challenge the legality of Point 13 of the uniform regulations banning "clothing of religious adherence" in court. In accordance with subparagraphs 3, 6 and 7 of chapter II of Article 49 of the Law of the Republic of Kazakhstan No. 319 - III, on Education, dated 27 July, 2007, parents and other legal representatives of minor children shall have a right to acquire information from the educational organizations regarding the progress; fulfil the requirements imposed to an obligatory school uniform, established by authorized body in the field of education. In accordance with the current legislation of the Republic of Kazakhstan, in respect of parents whose children do not comply with the school uniform, administrative punishment may be applied (Law on Education of the Republic of Kazakhstan). The law has been adopted and the society has split into two parts. One part totally agrees with the new law. For instance, the first President of the Republic of Kazakhstan said it is necessary to take measures on the ban of certain Islamic clothes. "Kazakhs wear black garments only for funerals," said Nazarbaev ('Black Is Only For Funerals!' Kazakh President Calls For Ban Against Islamic Attire, 2020).

The topic of religious dress is important for the authority and the government in the republic due to the three factors. First of all, students should not break secular norms.

Kazakhstan became independent from the Soviet Union in 1991, and according to the Constitution of the Republic of Kazakhstan, Kazakhstan is a democratic, legal, social and secular state where religion is separated from the authority with a special system of education and upbringing (Constitution of the Republic of Kazakhstan, 1995). The population of the Republic of Kazakhstan was 18,395,567 people on 12 April 2019, according to the statistical committee of the Ministry of National Economy of the Republic of Kazakhstan.

Second of all, new destructive movements in religion have appeared. As noted during the Soviet dictatorship, the confession of religion was forbidden. Right after independence, new 
religious opportunities opened up for all citizens. The Republic from the beginning of the independence started to develop diplomatic affairs with Islamic countries, for example, with the United Arab Emirates, Egypt, Iraq, Iran, Qatar, Yemen, and Tunisia, to find investors to build and renovate mosques, madrasah, and universities, to make exchange programmes for students. Thus, certain agreements have been signed between countries. Moreover, missioners brought new movements of religion. The new movements of religion appeared in the hard times for the country as legislative, executive and judiciary norms and bases were being discussed after becoming independent from the Soviet Union. It was a question of the time. The country was in progress, and it took time to settle everything. It is why it became an easy process because there was an ideological vacuum left in the country after the collapse of the Soviet Union. Missioners did good agitation through money, free courses and free education.

Thirdly, Kazakhstan has a lack of imams, which lead to serious problems such as enforcement of wrong and dangerous ideas through religion.

According to imams, the percentage of people in Kazakhstan who follow all norms of the Islamic religion are between $7 \%$ and $11 \%$, which is not high in comparison to other Central Asian countries such as Uzbekistan, Tajikistan or Kyrgyzstan (Nogoybayeva, 2017). The number of mosques has been increasing since the declaration of independence. According to the data published in connection with Central Asian Countries, there were 68 mosques in 1991 in Kazakhstan. However, in 2016, there were already 2516 mosques in the country, and 3601 mosques were registered in 2018. Despite the increased number of mosques in Kazakhstan, the number of imams in proportion to the inhabitants is lower. It is one of the most serious problems, which must be solved, because people cannot get proper assistance, which can lead to the misunderstanding of the religion. As a result, people are confused and accept unfamiliar norms in religion and culture as well.

Personally, I think it is a right decision to adopt such a law. However, it is seen as a violation of the right to freedom of religion. In the next subparagraph I will have a look at the right to freedom of religion in Kazakhstan.

\section{Religious garments and the right to freedom of religion in Kazakhstan}

The right to freedom of religion in Kazakhstan requires special attention due to the fact that the topic is becoming a legal and more importantly a political question nowadays (Smagulov, 2011).

I shall argue that the development of the right to freedom of religion in the territory of Kazakhstan has changed during the different regimes due to the approaches of the state. As 
noted above in the subparagraph on Islam in Kazakhstan, Muslims of Kazakhstan witnessed a wave of different approaches toward religion (Ohlsson, 2014).

I would venture to say that people in Kazakhstan have the right to freedom of religion. However, the limitations should exist, and it should be a natural practice in every state. I would like to point out again that limitations have been adopted in order to separate unknown beliefs and traditions in religion. As mentioned previously, the reasons for the changes in the legislative documents are necessary to ensure national security, and prevent extremism and terrorist threats.

The right to freedom of religion is a fundamental human right. The present situation with the right to freedom of religion in Kazakhstan is complicated. Kazakhstan has adopted the International documents on the protection of human rights. However, it is seen as a formal point the state has done. I disagree with the statement in the point of formality. I think the state has made a successful climate for confessing any religion. Within a short period of time, the government has made steps to protect the right to religion. I would like to underline its activities to protect the right to religion. First of all, I would like to mention that the right to freedom of religion has been articulated in the Universal Declaration of Human rights. Article 18 of the Universal Declaration of Human rights states that:

"Everyone has the right to freedom of thought, conscience and religion; this right includes freedom to change his religion or belief, and freedom, either alone or in community with others and in public or private, to manifest his religion or belief in teaching, practice, worship and observance". (Universal Declaration of Human Rights, 2948).

Kazakhstan has ratified international pacts and agreements that regard religious freedom including the International Covenant on Civil and Political Rights ratified on 28 November 2005; the Convention on the Rights of the Child on 8 June 1994; and the Optional Protocol to the International Covenant on Civil and Political Rights on 11 February 2009 (Podoprigora, 2017). Besides the mentioned international documents on the protection of human rights, Kazakhstan ratified the International Covenant on Civil and Political Rights in 2005 (International Covenant on Civil and Political Rights, adopted and opened for signature, ratification and accession by General Assembly resolution 2200A (XXI) of 16 December 1966).

All these international human rights instruments contain provisions, which concern different aspects of freedom of conscience and religion (belief) related to the express provision and protection of this right, as well as guaranteeing no discrimination on the grounds of religion.

There is a statement that the government of the republic was not interested in improving the situation with human rights. Podoprigora (2002) argues that the issues of religious freedom, relationships between law and religion, the state and believers or their associations also do not hold a large amount of interest for the government, the legal scholars or practical lawyers in Kazakhstan. 
It is a partially true statement. The government paid less attention due to the other aims of the country, but the government of the Republic of Kazakhstan has always been interested in questions of improving a situation with human rights. At the dawn of its independence, the issues of economic character have been the preference of the country. However, the situation has changed. The government, civil activists, international organizations and lawyers are working on programs and plans of improvement of the right to freedom of religion.

The rights of citizens are described in the constitution. According to Article 19 of the Constitution of the Republic of Kazakhstan, everyone shall have the right to determine and indicate or not indicate his religious affiliation. In Kazakhstan, a special law regulating relations in the religious sphere was the Law on Freedom of Religion and Religious Associations ('O svobode veroispovedaniya i religioznykh ob"yedineniyakh'), adopted on 15 January 1992 (The Law "On Freedom of Religion and Religious Associations in the Republic of Kazakhstan, 1992).

However, the law is no longer in force but the essence is saved and the articles have been adjusted. The current law which regulates relations in the religious sphere is the Law on Religious Activity and Religious Associations. The law has shortages that are unclear and controversial. Amendments to the law were adopted in 2011. It is important to note that the amendments have changed the regime of the state and religious relations in Kazakhstan (Service, 2020). Among the adopted amendments, I would like to highlight the strict process of registration of religious organizations, distribution of religious literature and other amendments which are criticized by the International organizations on protection human rights. (The Law on Religious Activities and Religious Associations, 2011).

For instance, according to the article on international instruments influencing religious freedom in Kazakhstan, the state takes control over religious worship, obligatory registration of religious associations, missionary activity, and dissemination of religious literature, alternative military service, and many other issues which make barriers for the existence of religions (Podoprigora and Klyushev, 2018).

This paper does not intend to analyze all of these, but it will provide a brief overview of some articles of the law, which seem to be contradicting. The first article that should be analyzed is Article 1 of the Law on Religious Freedom and Religious Associations. Article 1 includes the following statement: the current law guarantees a realization of the right to freedom of religion, which is articulated in the Constitution and other International documents and agreements on the protection of human rights. Limitations or restrictions of the right to confess religion shall be done in order to protect public order and safety, and the life, health, morals or rights and freedom of the citizens.

The modified Law on Religious Activity and Religious Associations starts with the statement that the law is based on the fact that the Republic of Kazakhstan represents itself as a 
democratic, secular state, and affirms the right of everyone for freedom of conscience, guarantees equal rights of everyone regardless of religious beliefs, recognizes the historical role of Hanafi Islam and Orthodox Christianity in the development of culture and spiritual life of the people, respects other religions, combined with the spiritual heritage of the people of Kazakhstan, and recognizes the importance of interreligious harmony, religious tolerance and respect for religious beliefs of citizens. In the current law we can also see the state's preference to two religions.

The first article of the law shows the main point which is a guarantee of realizing the right to freedom of religion. The current constitution of the Republic of Kazakhstan regards the right to freedom of conscience, and not the right to freedom of religion as stated in the law. It is important to note that the law guarantees the right to freedom of religion (conscience), enshrined not only in the Constitution of the Republic of Kazakhstan, but also in international legal acts and agreements, which may contain somewhat different provisions from those of Kazakhstan concerning the issues under consideration. I have already listed the agreements above, but it is important to add more agreements which protect human rights and the right to religion as well: the Final Act of the Conference on Security and Cooperation in Europe (1975), Final Document of the Vienna Meeting of Representatives of States Parties to the Conference on Security and Cooperation in Europe (1986), Document of the Copenhagen Meeting Conference on the Human Dimension of the Conference on Security and Cooperation in Europe (1990). In addition to this, The Declaration on the Elimination of All Forms of Intolerance and of Discrimination Based on Religion or Belief (1981) is an important document which, on the one hand, is not universally binding, but which, on the other hand, is now called upon by many countries when it comes to religious freedoms.

Very often, religious activities are public in nature, affect the interests of others, and in some cases involve harm to the health of citizens, the state or public interest. According to the generally accepted approach adopted today in many countries of the world, and in international legal practice, freedom of conscience (religion, belief) is absolute, but the freedom of action based on religion (confession, religious practice) is subject to state regulation and restrictions. Introducing prohibitive and restrictive norms in the legislation of different countries of the world towards believers and religious associations is often motivated by the protection of public order and morality. The policy of Kazakhstan towards religion is harsh and motivated by the same reasons.

For instance, Article 3 of the Law on Religious Activities and Religious Associations requires the separation of schools from religious organizations and the secular nature of education. The public education shall be separated from religious associations and shall have a secular nature. 
Parents have the right to bring up their children in accordance with their beliefs, but no coercive measures should be taken to involve their children in religion. The religious education of children must not harm their physical or mental health or moral development.

In this case, the regulation applies to all institutions of the public education system: kindergartens, schools, colleges, universities, and so on. Separation means that religious disciplines cannot be taught in public educational institutions, nor can religious rites, services, ceremonies or other activities related to the practice of religion be performed in those institutions. State institutions may teach disciplines related to religion such as the history of religions, modern religions, and sociology of religion, Muslim law, and religious studies. They shall provide general knowledge on religion, which should not be confessional in nature.

A serious problem in secular Kazakhstan is the manifestation of religious symbols in public places, including the wearing of traditional clothing and items that are the characteristic of the followers of any religion (hijabs, scarves, turbans, and any other garments which show affiliation to a particular group). This problem is most acutely expressed in schools. For several years now, Kazakhstan has been discussing a draft law that would prohibit the wearing of clothing that interferes with facial recognition in public places.

Kazakh legislation does not provide any guidance in this regard. On the one hand, from the standpoint of international legal norms, the right to freedom of thought, conscience, religion or belief includes the freedom to acquire and use, to an appropriate extent, necessary objects and materials related to religious rites, customs or beliefs. On the other hand, the principle of separation of schools from religious associations implies that the manifestation of religious symbols (if indeed, for example, the wearing of appropriate clothing is an integral part of religious practice) should be restricted in public educational institutions. There is an amendment in the Law on Education that prohibits wearing Islamic garments in school. The step of prohibition has been taken after some European countries had adopted similar legislation and the European Court of Human Rights had found that it did not violate citizens' rights in any way.

Any religion has certain attributes, rites and traditions. By banning the wearing of certain religious clothing, the state interferes in the sphere of private life and religious freedom. It is a violation of the right. However, according to subparagraph 7 of Article 3 of the Law on Religious activity and Religious Associations, nobody has the right to refuse, based on their religious beliefs, to perform the duties, prescribed by the constitution and the laws of the Republic of Kazakhstan. The constitution is the ruling document and all the principles must be followed. Moreover, the practice of international organizations and courts show that the right to freedom of religion of individuals can be violated if it is necessary to protect the whole society or state. 


\section{Conclusion}

Kazakhstan is a country which has recently started to make its own history. Since its independence from the Soviet Union, Kazakhstan has tried to develop all spheres and has achieved many positive results. In my point of view, the question of religion and religious garments, which has appeared recently, is due to several reasons. First of all, it is a vacuum of knowledge about religion which was left after the collapse of the Soviet Union. The second reason is that most young people are uneducated in terms of religion, and they are more susceptible for changes. If we have a look at the development of Islamic in Kazakhstan, we can conclude that Muslim religious garments have never been worn by Kazakh women. Kazakhs have their own traditional clothes, which represent their identity.

According to the previously mentioned studies, more people of the young generation in Kazakhstan wear religious clothes than people who are over 45. Moreover, this issue is bound to social and economic problems in the country. People try to find answers for their problems in religion, sometimes in non-conventional religions, because they cannot identify the right one. Undoubtedly, the government is working on this problem. What is more, the Ministry of Religious Affairs was turned into the Committee for Religious Affairs of the Ministry of Information and Social Development of the Republic of Kazakhstan.

I think, people in Kazakhstan have constitutional rights and everyone shall have the right to the freedom of conscience. In theory, citizens have freedom of choice and the state and the religion are separated, but in practice, the state will always interfere in questions regarding religions (traditional and nontraditional). It can be explained in several ways. Religions, especially Islam in Kazakhstan, will be determined and influenced by the state because there are many movements in religion (extremism, other forms of sects) nowadays which affect people and stability of the country. On the one hand, the position of the country is understandable because there may be different dangers, for instance, destroying national identity, forcing changes of the constitutional system, and undermining state security, among others. It can be done through people who believe in destructive religions. Therefore, the government has to formulate measures to prevent it.

The first measure to take should be and open dialogue with pupils, students and authorities in every school and university. The authorities of each city should conduct discussions with their citizens. For instance, they can organize meetings in those schools and universities where problems arose. Pupils and students and their parents have to understand the mechanism of the secular form of education, which means that state bodies should organize and provide them free education (primary and secondary education are free of charge),( Constitution of the Republic of Kazakhstan, 1995) and they must follow the rules set 
by the government or the Ministry of Education and Science. Most schools and universities are registered by the Ministry of Education and Science of the Republic of Kazakhstan.

One of the important steps is to provide knowledge on religion. The Ministry has already included the course of Secularism and Foundations of Religious Studies in the curriculum. The main aims are to give important knowledge about freedom and consience, history and current traditional religions, new religious movements, distructive religious movements and to recognise ideologies of terrorism, extremism, and other forms of distructive religions (Cornell, Starr and Tucker, 2018).

The state with its official bodies must solve problems of social and economic characters. For instance, people who are into deep untraditional religion are mostly unemployed in Kazakhstan. According to different reports, they face problems such unemployment, lack of money, low standard of living, etc.

Moreover, parents must be involved more in the process of education and upbringing. Kazakhstan from its side has provided all necessary conditions for pupils and students. All students receive their education based on the constitution, other documents and pacts which were adopted to protect their fundamental rights.

I believe the limitation should be the last measure to stop people wearing untypical clothes in the institutions of public education in Kazakhstan. However, limitation is the only measure for now which can prevent it.

\section{References}

Constitution of the Republic of Kazakhstan, 1995.

NOGOYBAYEVA, E., 2017. Central Asia: A Space For "Silk Democracy": Islam And State. Almaty: Friedrich Ebert Foundation, pp.30-31.

A. HIRSCHFIELD, K. CRISTMAN, A. WILCOX, M. ROGERSON, K. SHARAT ., 2012. Process Evaluation of Preventing Violent Extremism Programmes for Young People.

ACHILOV, D., 2012. Islamic Education in Central Asia: Evidence from Kazakhstan. Asia Policy, 14(1), pp.79-106.

BENNIGSEN, A., 1983. Мусульмане B CCCP (Muslims In The USSR).

JAMIE BARTLETT \& CARL MILLER, 2011. The Edge of Violence: Towards Telling the Difference Between Violent and Non-Violent Radicalization.

Law on Education of the Republic of Kazakhstan.

LEVSHIN, A., 1832 [online] ljbssnet.com. Available at: <https://ijbssnet.com/journals/Vol_3_No_11_June_2012/15.pdf> [Accessed 22 April 2020]. 
MARININ, S., 2015. State Regulation of Religion in Kazakhstan: Reconsideration of Approaches.

MIGACHEVA, K. AND FREDERICK, B., n.d. Religion, Conflict, And Stability In The Former Soviet Union.

NOGOYBAYEVA, E., 2017. Central Asia: A Space For "Silk Democracy": Islam And State. Almaty: Friedrich Ebert Foundation, pp.30-31.

TORLANBAYEVA, K., 2017. Chokan Valikhanov on Islam among the Kazakhs.

National report "Youth of Kazakhstan - 2018".

RadioFreeEurope/RadioLiberty. 2020. 'Black Is Only For Funerals!' Kazakh President Calls For Ban Against Islamic Attire. [online] Available at: <https://www.rferl.org/a/kazakhstannazarbaev-banning-islamic-dress-black-funerals/28447008.html> [Accessed 22 April 2020].

SMAGULOV, K., 2011. The Religious situation today in Kazakhstan.

OHLSSON, H., 2014. Teaching About Religion in a Post-Soviet State: An Examination of Textbooks in Kazakhstan's Upper Secondary School system.

PODOPRIGORA, R., 2002. State and Religious Organizations: Administrative and Legal Matters.

PODOPRIGORA, R., 2017. Religious Freedom and Human Rights in Kazakhstan.

PODOPRIGORA, R. AND KLYUSHEV, A., 2018. International Instruments Influencing Religious Freedom in Kazakhstan. The Review of Faith \& International Affairs, 16(2), pp.9095.

Service, F., 2020. Forum 18: KAZAKHSTAN: President Signs Two Laws Restricting Freedom Of Religion Or Belief - 13 October 2011. [online] Forum18.org. Available at: <http://www.forum18.org/archive.php?article_id=1624> [Accessed 22 April 2020].

International Covenant on Civil and Political Rights. Adopted and opened for signature, ratification and accession by General Assembly resolution 2200A (XXI) of 16 December 1966. The Law "On Freedom of Religion and Religious Associations in the Republic of Kazakhstan, 1992.

The Law on introducing Amendments and Additions to several legal acts questions of Religious Activity and Religious Associations, 2011.

Constitution of the Republic of Kazakhstan, 1995.

CORNELL, S., STARR, F. AND TUCKER, J., 2018. Religion And The Secular State In Kazakhstan.

\section{Contact address}

Zhansulu Muratova

PhD student of the Doctoral School of Public Administration Sciences

National University of Public Service

1083 Budapest, Hungary, Ludovika tér 2.

E-mail address: Muratova.zhansulu@mail.ru; Muratova.zhansulu@gmail.com 